Research paper

\title{
Paleoenvironmental analyses of surface sediments from the Bohai Sea, China, using diatoms and silicoflagellates
}

\author{
Dongyan Liu ${ }^{\mathrm{a}, *}$, Lixue Liu ${ }^{\mathrm{a}, \mathrm{b}}$, Baoping Di ${ }^{\mathrm{a}}$, Yujue Wang ${ }^{\mathrm{a}}$, Yanna Wang a,b \\ ${ }^{a}$ Key Laboratory of Coastal Environmental Processes and Ecological Remediation, Yantai Institute of Coastal Zone Research, Chinese Academy of Sciences, 264003 Yantai, Shandong, PR China \\ ${ }^{\mathrm{b}}$ University of Chinese Academy of Sciences, 100049 Beijing, PR China
}

\section{A R T I C L E I N F O}

\section{Article history:}

Received 18 May 2014

Received in revised form 17 November 2014

Accepted 23 November 2014

Available online 3 December 2014

\section{Keywords:}

Diatoms

Silicoflagellates

Indicative species

Bohai Sea

Yellow River

\begin{abstract}
A B S T R A C T
Diatom and silicoflagellate fossils from surface sediments were analyzed at 63 sites in the Bohai Sea. Their spatial variations of the fossils were indicative of past environmental conditions, hydrodynamics, and the interaction of the Yellow Sea intrusion and Yellow River discharge into the Bohai Sea. In total, 162 taxa were identified. Higher species diversity and lower abundance occurred near the mouth of the Yellow River and Laizhou Bay, while lower species diversity and higher abundance occurred in the Central Bohai Sea and Bohai Strait. The spatial differences between fossil diversity and abundance are strongly related to the freshwater and sediment inputs from the Yellow River; lower salinity provides a diverse habitat for brackish and marine species, while a higher deposition rate can dilute the fossil concentrations.

Three distinct biofacies representing the Laizhou Bay, Central Bohai Sea and Bohai Strait were classified after principal component analysis. The dominant species along the salinity gradient shifted from Paralia sulcata in the Bohai Strait to Cyclotella stylorum and Dictyocha messanensis in the Laizhou Bay, while a mixing zone existed in the Central Bohai Sea. The canonical correspondence analysis between major species and environmental factors indicated a relationship between $P$. sulcata and the Yellow Sea intrusion, with significant positive correlations being observed between salinity gradient, water depth and autumn temperature. In comparison, C. stylorum and D. messanensis were related to the discharge of the Yellow River, having significant positive correlations with the low-salinity and nutrient-rich environment.
\end{abstract}

(c) 2014 Elsevier B.V. All rights reserved.

\section{Introduction}

Diatoms are the dominant phytoplankton in most aquatic habitats and make a significant contribution to primary production (Dawes, 1998). In contrast, silicoflagellates are rarely dominant and make a smaller contribution to primary production. However, both groups are sensitive to variable environmental factors, and have siliceous structures that easily preserve in sediments and are widely used for reconstructing the paleo- or modern-environmental conditions (Battarbee et al., 2001; Smol and Stoermer, 2010). Many case studies have demonstrated that diatom and silicoflagellate fossils are reliable proxies for interpreting variations in paleo-temperature, salinity and even eutrophication at a variety of latitudes in both hemispheres (e.g., Sancetta, 1990; Whitehead and Bohaty, 2003; Jiang et al., 2004; Berglund et al., 2005; Barron and Burky, 2007; Buffen et al., 2007). For example, Berglund et al. (2005) traced the changes of coastal evolution and sea level in Blekinge, Sweden, using the ratios of marine, brackish and freshwater diatoms; Whitehead and Bohaty (2003) used the ratio

\footnotetext{
* Corresponding author at: Yantai Institute of Coastal Zone Research, CAS, 17th Chunhui Road, Laishan District, 264003 Yantai, China. Tel./fax: + 865352109116.

E-mail address: dyliu@yic.ac.cn (D. Liu).
}

between warm water Dictyocha and cold water Distephanus species to reconstruct variations in the paleo-temperature of the Southern Ocean.

The Bohai Sea is a large and shallow inland sea with an average water depth of $18 \mathrm{~m}$ and a total area of $77,000 \mathrm{~km}^{2}$ (Fig. 1a). It consists of five parts: Liaodong Bay, Bohai Bay, Laizhou Bay, Central Bohai Sea and Bohai Strait. The Bohai Strait is the only entrance connected to the Yellow Sea. The topography of the Bohai Sea is characterized by a basin shape, with water depths $>20 \mathrm{~m}$ in the Central Bohai Sea and Bohai Strait, but generally $<20 \mathrm{~m}$ in the three coastal bays (Fig. 1a). Two major hydrodynamic factors, the Yellow Sea intrusion and Yellow River discharge, have profoundly influenced the thermohaline circulation and sedimentary environment in the Bohai Sea. In winter, the Yellow Sea Warm Current (YSWC) with a warm and salty character is driven by the incursion of a branch of the Kuroshio subsurface water onto the shelf, extends northward and can reach the Bohai Sea. The current moves westward along the central part of the sea and splits into two branches: one moving toward the northeast to form a clockwise gyre (Liaoxi Coastal Current) and another moving southward and then turning eastward along the southern coast to form a counterclockwise gyre (Lubei Coastal Current; Fig. 2a) (Guan, 1994; Su, 1998). In summer, the YSWC disappears in the Bohai Sea, and the eddies produced by the Bohai Sea itself are stronger than in winter. The positions 

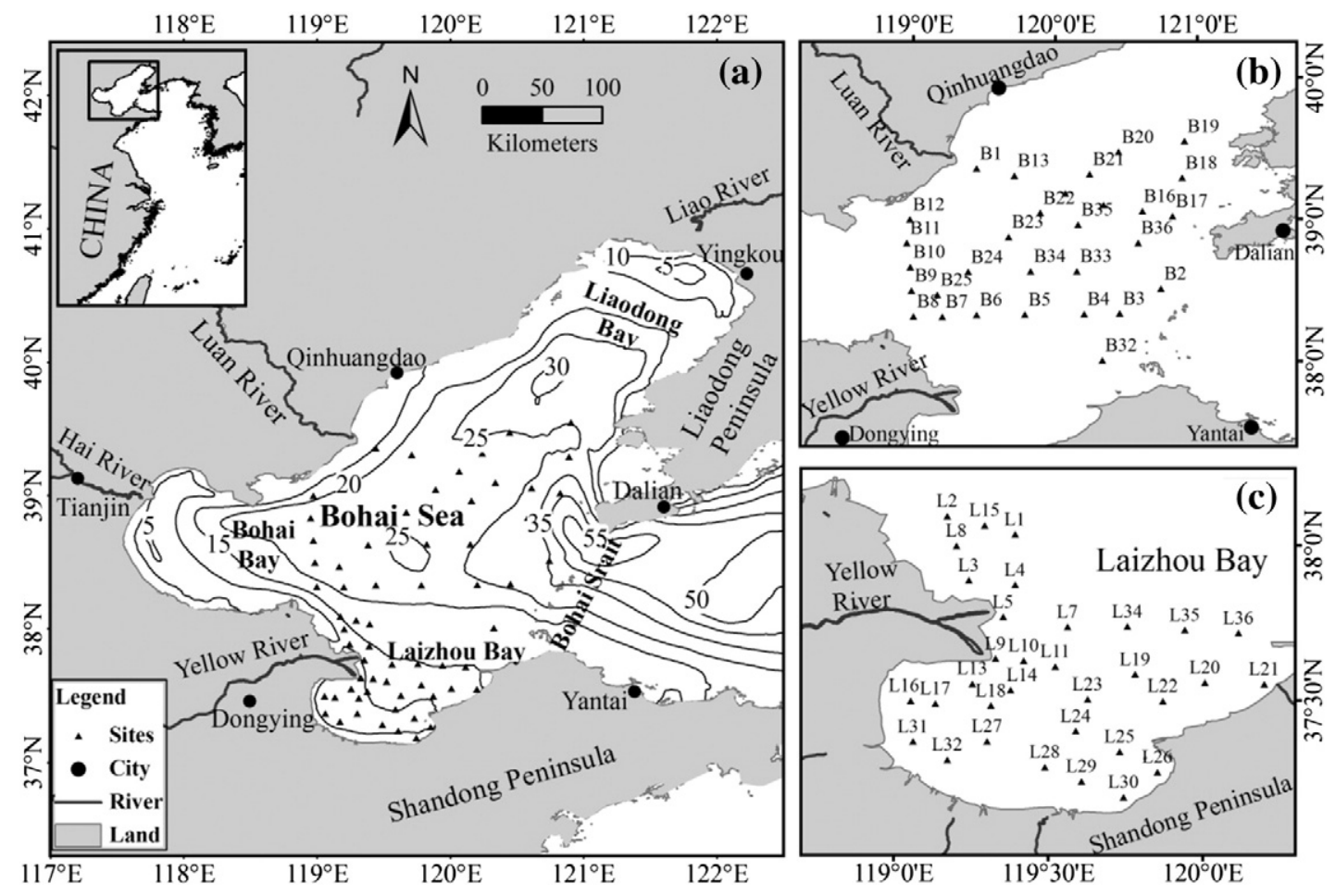

Fig. 1. (a) Map of the Bohai Sea with water depth and sampling sites; (b) sampling sites in the Central Bohai Sea; and (c) sampling sites in the Laizhou Bay.

and directions of the eddies, however, are slightly different; the central eddy is missing, while the eddy in the Laizhou Bay is more pronounced, and a coastal current along the southern and western coastlines of the Bohai Sea is established (Fig. 2b) (Hainbucher et al., 2004). The Laizhou Bay connects to the entrance of the Yellow River, which is one of the largest rivers in the world. The Yellow River provides approximately $50 \%$ of the freshwater discharged into the Bohai Sea along with $10^{9} \mathrm{t}$ of suspended solids every year (Wang et al., 2006). Therefore, Yellow River discharge profoundly impacts the nutrient levels, thermohaline circulation and sedimentary environment in the Laizhou Bay and adjacent areas, and the Yellow River plume can even flow northeastward into the Central Bohai Sea and Bohai Strait (Lin et al., 2001; Wang et al., 2006; Liu et al., 2011).

The spatial variations of interactions between the Yellow Sea intrusion and the Yellow River discharge in the Bohai Sea, however, are not clear. Based on sea surface temperature variations, Hickox et al. (2000) found a clear coastal front near the Bohai Strait where water depths are more than $50 \mathrm{~m}$, indicating that the Yellow River plume can reach the Central Bohai Sea. Mao et al. (2008) simulated the spatial variation of salinity in the Bohai Sea and determined that the diluted water of the Yellow River primarily affects the salinity in the Laizhou Bay, while the Central Bohai Sea and Baohai Strait were influenced by the Yellow Sea intrusion, showing little correlation with the Yellow River discharge. Consequently, the phytoplankton assemblages in the water column reflected the spatial differences; they were grouped into coastal and central patterns using the ratios of brackish species (e.g., Cyclotella stylorum) to marine species (e.g., Paralia sulcata) (Sun et al., 2002; Sun and Liu, 2005). However, Liu and Wang (2013) reported the decadal variation of chlorophyll $a$ concentrations in the Bohai Sea and found that there are three water depth-related patterns: a clear coastal pattern $(<20 \mathrm{~m})$, a mixing pattern $(20-40 \mathrm{~m})$ and an offshore pattern $(>40 \mathrm{~m})$. This indicates that a mixing zone exists in the Central Bohai Sea. Jiang (1987) presented a similar three-layer pattern using diatom fossils in surface sediments and suggested that salinity and water depth were key factors determining this pattern. The above evidence indicates that the Yellow River impact might reach the Central Bohai Sea.
In this sense, the present study attempts to use diatom and silicoflagellate fossils in surface sediment as ecological indicators to achieve two goals: 1) to map the geographical distributions of siliceous microfossils and characterize their relationships with the Yellow Sea intrusion and Yellow River discharge in the Bohai Sea; and 2) to explore the key environmental factors to determine the spatial patterns of the fossils. We chose 63 sites in the Bohai Sea including the Laizhou Bay, which is significantly affected by the Yellow River discharge, and the Central Bohai Sea and Bohai Strait, which are significantly affected by the Yellow Sea intrusion (Fig. 1b, c). Species composition and the abundance of siliceous microfossils in the surface sediments were analyzed, and their assemblages were mapped and classified based on the similarity analysis. The correlation between siliceous microfossils and related environmental factors, including water depth, sediment grain size, deposition rate, temperature, salinity and nutrients, were discussed to discern the roles of fossils as indicators of environmental conditions.

\section{Materials and methods}

\subsection{Study area and sampling methods}

The Bohai Sea is a typical temperate area (Fig. 1a). The annual average seawater temperature is approximately $12.3^{\circ} \mathrm{C}$, with a maximum in August $\left(22.5-27.7^{\circ} \mathrm{C}\right)$ and a minimum in February $\left(-0.5-2.5^{\circ} \mathrm{C}\right)$ (Lin et al., 2001). The annual average salinity is approximately 30.0 , with higher values near the Bohai Strait $(>31.0)$ and lower values in the Laizhou Bay (22-26.0) (Lin et al., 2001). The Laizhou Bay is located in the south of the Bohai Sea and connects to the Yellow River mouth (Fig. 1c). The total area is approximately $11,603 \mathrm{~km}^{2}$, and the water depths in most areas are less than $10 \mathrm{~m}$.

In this study, 33 sites in the Laizhou Bay and 31 sites in the Central Bohai Sea were chosen for the analysis of siliceous microfossils. The surface sediments were collected using a box corer $\left(0.1 \mathrm{~m}^{2}\right)$ at each site during summer cruises in 2011, and the top $2 \mathrm{~cm}$ were taken and kept in a freezer on the ship. They were then transferred to a laboratory 
for the analysis of siliceous microfossils and the measurement of grain sizes.

\subsection{Slide preparation}

The sediment samples were processed according to the methods described by Renberg (1990) and Battarbee et al. (2001). All samples were dried at $105{ }^{\circ} \mathrm{C}$ and treated with $10 \% \mathrm{HCl}$ overnight to remove carbonate along with some metal salts and oxides. The samples were then washed using distilled water and settled to remove organic matter. The samples were treated with $30 \% \mathrm{H}_{2} \mathrm{O}_{2}$, and the reaction was allowed to continue until all organic matters were removed. After the removal of remnant $\mathrm{H}_{2} \mathrm{O}_{2}$ using distilled water, the samples were treated with ammonium hydroxide solution to partially reduce the impact of clay. After rinsing several times to remove chemical residues, zinc bromide (specific gravity 2.4) was added to the samples to separate siliceous microfossils. The samples were centrifuged at 2000 rotations/minute for $10 \mathrm{~min}$ to suspend the siliceous microfossils. The suspended fossils were diluted to certain volumes, and aliquots were placed onto cover slips. After the materials had completely dried, the cover slips were transferred to labeled permanent mounts with Naphrax.

\subsection{Identification and enumeration of diatom and silicoflagellate fossils}

Slides were examined under an Olympus CX-31 light microscope. Taxonomy and nomenclature followed those of Chin et al. (1992), Cheng et al. (1996), Hasle et al. (1996), Guo and Qian (2003) and algaebase (www.algaebase.org). Pleurosigma and spores of the genus Chaetoceros were not identified to species level due to unclear features under the light microscope. Only two silicoflagellate species

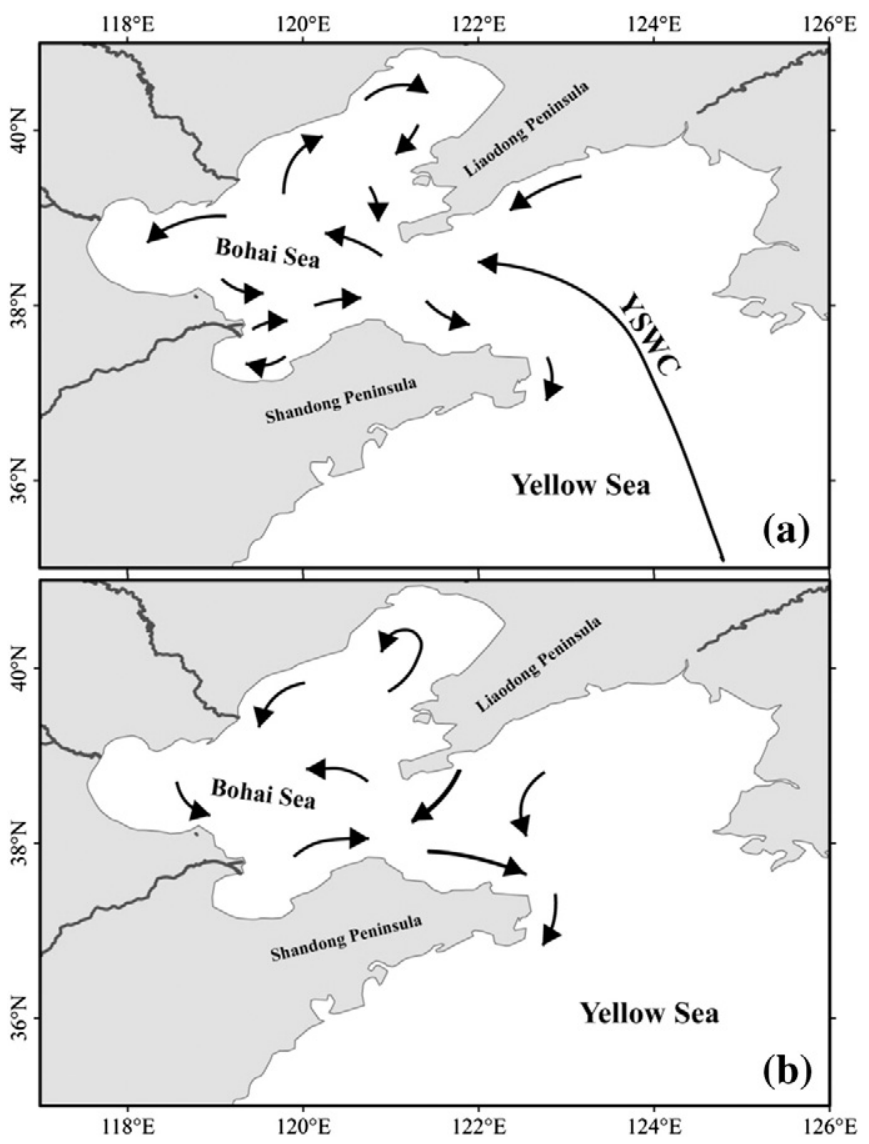

Fig. 2. Winter (a) and summer (b) circulation features in the Bohai Sea, redrawn from Guan (1994).
(Dictyocha messanensis and Distephanus speculum) were identified on the slides. D. messanensis showed high abundance at most sites, while D. speculum was only observed at three sites with very low abundance, and thus is not discussed here in further detail.

A total of at least 300 siliceous microfossils (diatoms and silicoflagellates) were counted in up to three slides prepared from each sample. The absolute abundances are expressed as numbers of individuals per gram of dry sediment (valves/g DW for diatom fossils and
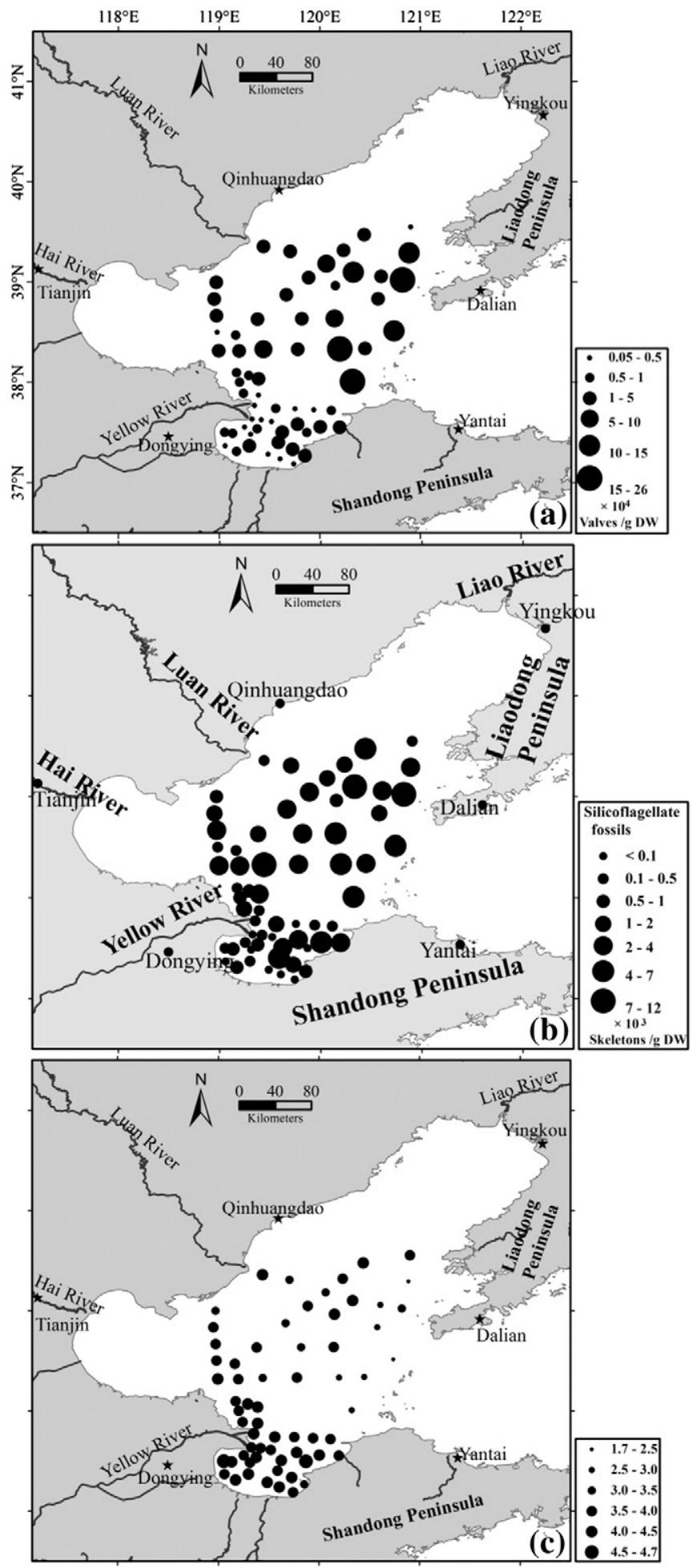

Fig. 3. The spatial distribution of total abundance in diatoms (a), silicoflagellates (b) and Shannon-Wiener index $\left(H^{\prime}\right)(\mathrm{c})$. 
skeletons/g DW for silicoflagellate fossils; DW is dry weight) and calculated as follows:

$D_{[a b s]}=\frac{n v}{v_{1} w}$

where $D_{a b s}$ is the absolute abundance, $n$ is the total number of individuals counted on the slides, $v$ is the volume to which the suspended fossils were diluted, $v_{1}$ is the volume of the aliquots dropped on the slides, and $w$ is the dried weight of the samples.

\subsection{Measurements of sediment grain size}

The sediment samples were oxidized by $10 \% \mathrm{H}_{2} \mathrm{O}_{2}$ to remove organic matter and dispersed in a $0.05 \%\left(\mathrm{NaPO}_{3}\right)_{6}$ solution to isolate discrete particles. The samples were then measured by a Mastersize 2000 Laser Particle Sizer. Grain sizes were classified into clay $(<4 \mu \mathrm{m})$, silt (4-63 $\mu \mathrm{m}$ ) and sand (>63 $\mu \mathrm{m}$ ) according to Folk's triangle classification and nomenclature (Folk et al., 1970).

\subsection{Data analysis}

The species diversity and richness indices were calculated according to the Shannon-Wiener index $\left(H^{\prime}\right)$ (Shannon and Weaver, 1949):

$H^{\prime}=-\sum_{i=1}^{s} P_{i} \times \log _{2} P_{i}$

where $H^{\prime}$ is the Shannon-Wiener index and $P_{i}$ is the ratio of the individuals of species $i$ to the total individuals of all species.

Diatom and silicoflagellate assemblages were grouped by similarity analysis using the multivariate statistical program in CANOCO Version 4.5 (Ter Braak and Smilauer, 2002). First, a linear principal component analysis (PCA) was performed on a matrix of species abundance proportions to identify the statistical significance of variation within samples (Buffen et al., 2007). As data varied in a narrow range (gradient length 2.65), the scores of the PC axis that can explain more than $65 \%$ of the variation were used as input variables to implement hierarchical cluster analysis (HCA). The HCA was performed using the average Euclidean distance linkage clustering method. Diatom and silicoflagellate assemblages were grouped based on the similarity results.
The correlations between the three major species and environmental factors (temperature, salinity and nutrients) were analyzed using canonical correspondence analysis (CCA) in the statistical program CANOCO Version 4.5 (Ter Braak and Smilauer, 2002). Environmental data were obtained from the averages of spring (May) and autumn (November) surveys in the Bohai Sea during 2010, 2011 and 2012. The correlations between the fossil parameters (absolute abundance, species diversity index) and the grain size proportion of sediments (clay, silt and sand) were analyzed using the software SPSS 20 (Statistical Product and Service Solutions) to evaluate the impacts of grain size on the preservation of fossil flora.

\section{Results}

\subsection{Spatial distribution of siliceous microfossils}

In total, 162 taxa were identified at 63 sites, including 74 centric diatoms, 82 pennate diatoms, and two silicoflagellate species (D. messanensis and D. speculum; Appendix I). The species composition in the Liaozhou Bay displays a significant combination of freshwater species (e.g., Melosira islandica, Hantzschia amphioxys), brackish species (e.g., C. stylorum, Thalassionema nitzschioides) and marine species (e.g., P. sulcata, Thalassiosira eccentrica), indicating the impact of freshwater input.

The abundances of diatom fossils range from $0.25 \times 10^{4}$ valves $/ \mathrm{g}$ DW to $24.7 \times 10^{4}$ valves/g DW, with higher values in the Central Bohai Sea and Bohai Strait and lower values in the sea area adjacent to the mouth of the Yellow River (Fig. 3a). The abundance of the silicoflagellate D. messanensis varies from 7 skeletons/g DW to $1.18 \times 10^{4}$ skeletons $/ g$ DW, with higher values in the coastal area and lower values near the Bohai Strait. D. speculum only occurred at three sites (L5, L7 and B5) near the mouth of the Yellow River with very low abundances $(5,19$ and 75 skeletons/g DW, respectively).

The Shannon-Wiener index $\left(H^{\prime}\right)$ varies from 1.71 to 4.64 , showing an opposite spatial pattern with abundance, with higher values in the sea areas adjacent to the mouth of the Yellow River and lower values near the Bohai Strait (Fig. 3b). The dominant species with abundance proportions over $10 \%$ at each site are mapped in Fig. 4 . A clear spatial pattern shows that $P$. sulcata displayed very high proportions at the sites close to the Bohai Strait. The dominant species gradually become

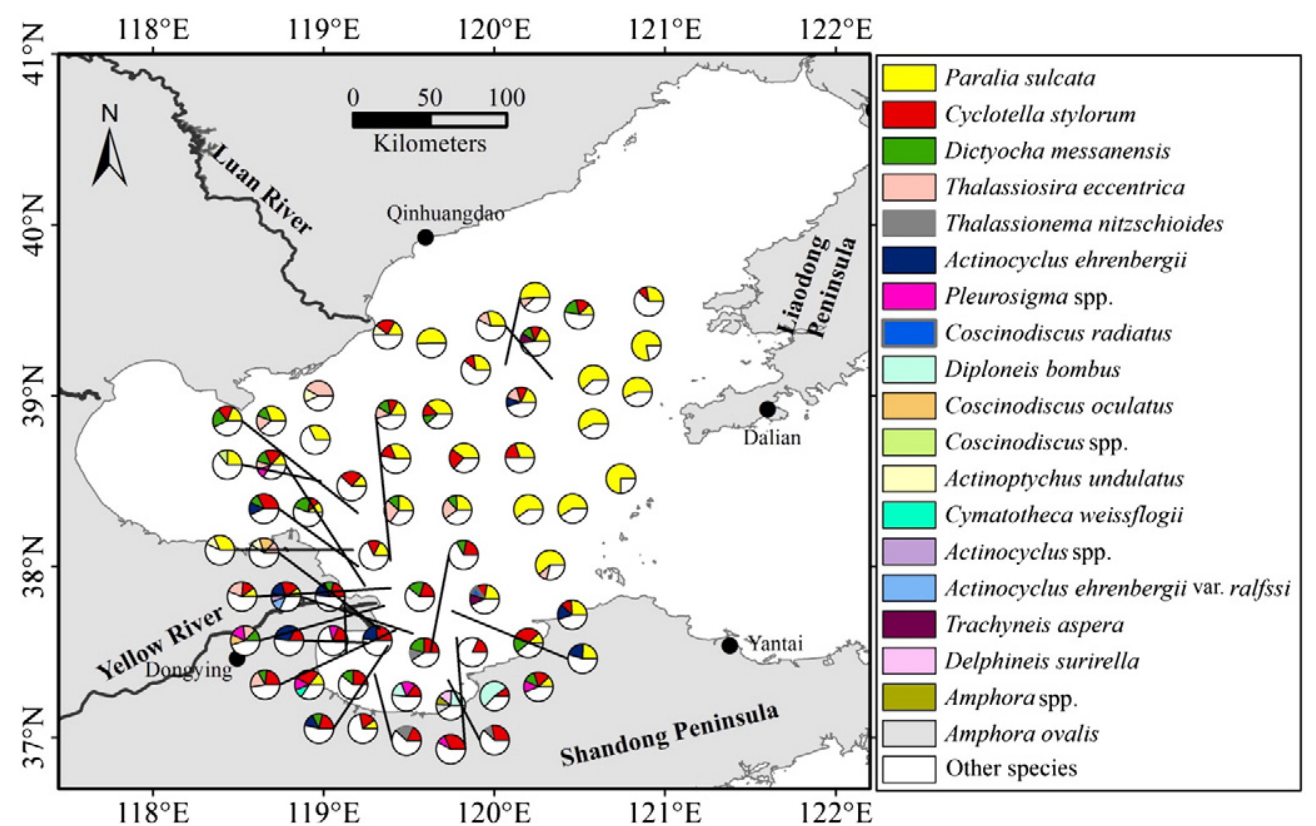

Fig. 4. The spatial distribution of dominant diatom and silicoflagellate fossils (proportion of abundance $>10 \%$ at each site) at the sampling sites. 
diverse from the Central Bohai Sea to the Laizhou Bay, with D. messanensis and C. stylorum distributed widely in high abundances.

\subsection{Spatial biofacies of siliceous microfossils}

The PCA and HCA results show that except for site B12, the siliceous microfossils at the sampling sites could be classified into three biofacies (Groups I, II and III; Fig. 5a). The biofacies distribution was mapped according to the sampling sites, showing a clear spatial geographic variation (Fig. 5b). Most sites near the Bohai Strait and the entrance of the Liaodong Bay belonged to Group I. The Central Bohai Sea was dominated by Group II, with a few mixed sites from Groups I and III. Group III mainly occurred in the Laizhou Bay and the sites close to the Luan River, indicating freshwater input.

Fossil abundance along with species richness and dominance in the three biofacies are shown in Table 1. Among the three groups, Group I

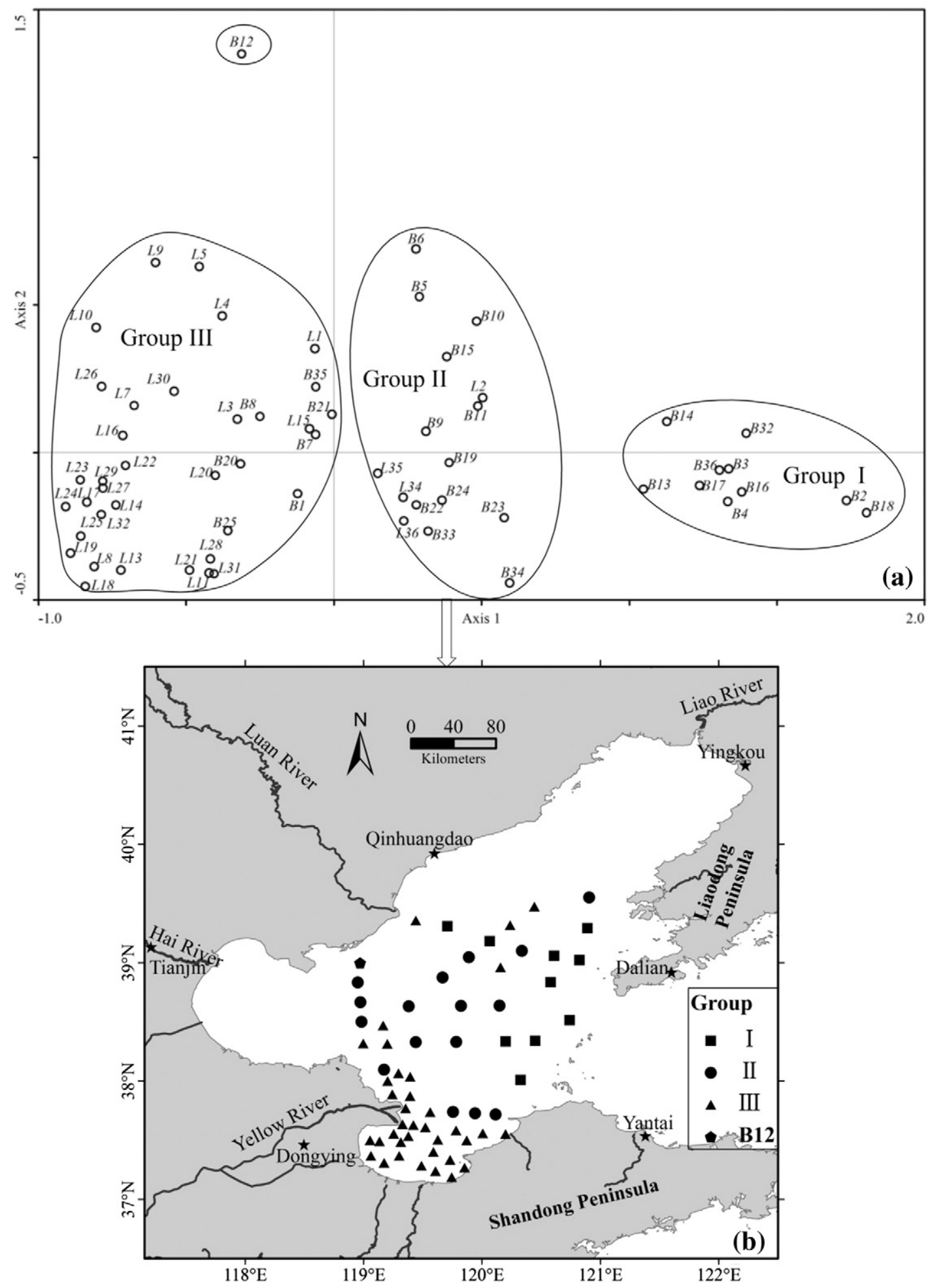

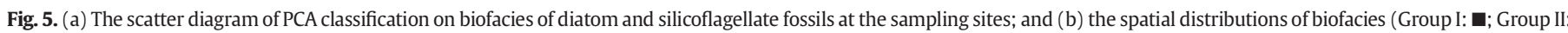
$\boldsymbol{0}$; and Group III: $\mathbf{\Lambda})$. 
Table 1

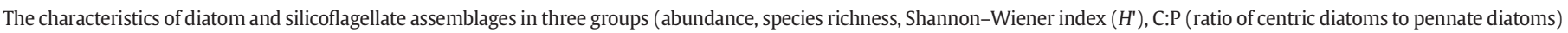
and dominant species composition).

\begin{tabular}{|c|c|c|c|c|}
\hline \multirow[b]{2}{*}{ Site numbers } & & \multirow{2}{*}{$\frac{\text { Group I }}{10}$} & Group II & Group III \\
\hline & & & 16 & 36 \\
\hline \multirow{2}{*}{$\begin{array}{l}\text { Diatom fossils } \\
\qquad\left(\times 10^{4} \text { valves/g DW }\right)\end{array}$} & Range & $2.38-24.7$ & $0.25-10.7$ & $0.46-3.16$ \\
\hline & Average & $10.2 \pm 7.23$ & $2.72 \pm 2.86$ & $0.93 \pm 0.82$ \\
\hline \multirow{2}{*}{$\begin{array}{l}\text { Silicoflagellate fossils } \\
\qquad\left(\times 10^{4} \text { skeletons/g DW }\right)\end{array}$} & Range & $0.15-0.99$ & $0.0009-1.18$ & $0.0007-0.58$ \\
\hline & Average & $0.41 \pm 0.28$ & $0.28 \pm 0.33$ & $0.13 \pm 0.15$ \\
\hline \multirow[t]{2}{*}{ Species richness } & Range & $37-55$ & $20-105$ & $22-137$ \\
\hline & Average & $47 \pm 4$ & $48 \pm 10$ & $47 \pm 14$ \\
\hline \multirow[t]{2}{*}{$H^{\prime}$} & Range & $1.71-3.19$ & $3.19-4.02$ & $2.28-4.64$ \\
\hline & Average & $2.64 \pm 0.38$ & $4 \pm 0.2$ & $4 \pm 0.22$ \\
\hline \multirow[t]{2}{*}{$\mathrm{C}: \mathrm{P}$} & Range & $8-21$ & $3-24$ & $1-20$ \\
\hline & Average & $12 \pm 3.4$ & $12 \pm 5.7$ & $6 \pm 3.7$ \\
\hline \multirow{12}{*}{$\begin{array}{l}\text { Dominant species } \\
\text { (percentage of abundance) }\end{array}$} & & Paralia sulcata (62\%) & Paralia sulcata (29\%) & Paralia sulcata (6\%) \\
\hline & & Thalassiosira eccentrica (5\%) & Thalassiosira eccentrica (14\%) & Thalassiosira eccentrica (5\%) \\
\hline & & Cyclotella stylorum (5\%) & Cyclotella stylorum (12\%) & Cyclotella stylorum (21\%) \\
\hline & & Dictyocha messanensis (4\%) & Dictyocha messanensis (9\%) & Dictyocha messanensis (11\%) \\
\hline & & Actinoptychus undulatus (3\%) & Actinoptychus undulatus (4\%) & Actinoptychus undulatus (3\%) \\
\hline & & Actinocyclus ehrenbergii (2\%) & Actinocyclus ehrenbergii (3\%) & Actinocyclus ehrenbergii (4\%) \\
\hline & & Podosira stelliger ( $2 \%$ ) & Podosira stelliger ( $4 \%$ ) & Coscinodiscus marginatus (3\%) \\
\hline & & & & Planktoniella blanda (4\%) \\
\hline & & & & Cymatotheca weissflogii (4\%) \\
\hline & & & & Diploneis bombus (4\%) \\
\hline & & & & Pleurosigma sp. (7\%) \\
\hline & & & & Thalassionema nitzschioides (6\%) \\
\hline
\end{tabular}

exhibited the highest abundance and the lowest species diversity. The average diatom abundance was $10.2 \times 10^{4}$ valves/g DW, with a maximum at site B17 $\left(24.7 \times 10^{4}\right.$ valves $/ g$ DW $)$ and a minimum at site B13 $\left(2.38 \times 10^{4}\right.$ valves/g DW). In total, 55 species were identified, with $H^{\prime}$ values ranging from 1.71 to 3.19 (average $=2.64$ ). The ratios of centric and pennate diatom fossils (C:P) range from 8 to 21 , with an average of 12, indicating the dominance of Group I planktonic species (Table 1). The dominant species are P. sulcata (62\%), T. eccentrica (5\%), C. stylorum (5\%), and Actinoptychus undulatus (3\%). The average proportion of $D$. messanensis reached $4 \%$ of the total microfossil count, with a range of $0.15 \times 10^{4}$ skeletons/g DW-0.99 $\times 10^{4}$ skeletons/g DW in abundance.

The average abundance of diatom fossils in Group II was $2.72 \times 10^{4}$ valves/g DW, which is much lower than that of Group I (Table 1). Species diversity, however, was higher than in Group I; the range of $H^{\prime}$ increases to 3.19-4.02, with an average of 4.0. In total, 105 species were identified. The values of C:P varied with a wide range of 3-24. Lower C:P values occurred at the sites close to coastal waters, indicating an increase in benthic species. P. sulcata was still dominant in Group II, although it showed a much lower abundance proportion (26\%) than in Group I. In comparison to Group I, the proportions of dominant T. eccentrica (11\%) and C. stylorum (10\%) are significantly higher in Group II. The average proportion of $D$. messanensis increased to $8 \%$, with an average abundance of $0.28 \times 10^{4}$ skeletons/g DW (Table 1 ).

Group III was characterized by the lowest abundance and the highest species diversity (Table 1 ). The average diatom abundance was only $0.91 \times 10^{4}$ valves/g DW, with a maximum of $3.16 \times$ $10^{4}$ valves/g DW at site L19 and a minimum of $0.05 \times 10^{4}$ valves $/ g$ DW at site L9. In total, 137 species were identified, and the range of $H^{\prime}$ increased to 2.28-4.64, with an average of 4.0. Compared with Groups I and II, the C:P decreased sharply in Group III, indicating a significant increase in benthic species (Table 1 ). The proportion of $C$. stylorum abundance increased to $20 \%$, while P. sulcata decreased to only $8 \%$. Moreover, brackish and benthic species displayed a significant increase, e.g., Pleurosigma sp. (6\%), T. nitzschioides (5\%), A. ehrenbergii (4\%), Diploneis bombus (3\%), Cymatotheca weissflogii (3\%), Trachyneis aspera (2\%), and Surirella fastuosa (2\%), indicating the impact of freshwater input. The role of $D$. messanensis increased significantly in the microfossil assemblage with an average proportion of $11 \%$, although an average abundance declined to $0.13 \times 10^{4}$ skeletons/g DW (Table 1 ).

\subsection{The grain size of sediments in the studied area}

Sediment grain sizes were analyzed at the sampling sites to understand its effect on the preservation of siliceous microfossils; the result is consistent with a previous study (Qiao et al., 2010). The finegrained sediments (mud, sandy mud and silt) dominated in the southern Central Bohai Sea, Laizhou Bay and the sea area close to the Luan River, indicating the contribution and impact of river inputs on sediments. Coarse-grained sediments ( silt sand and sand) only occurred in the sea area near the Bohai Strait (Fig. 6), which is characterized by the lack of river input and a fast tidal current that does not deposit fine sediment (Qiao et al., 2010).

\section{Discussion}

The siliceous microfossils in the surface sediment displayed a clear spatial pattern with distinct biofacies, with an abundance gradient of Group I > Group II > Group III and a species diversity gradient of

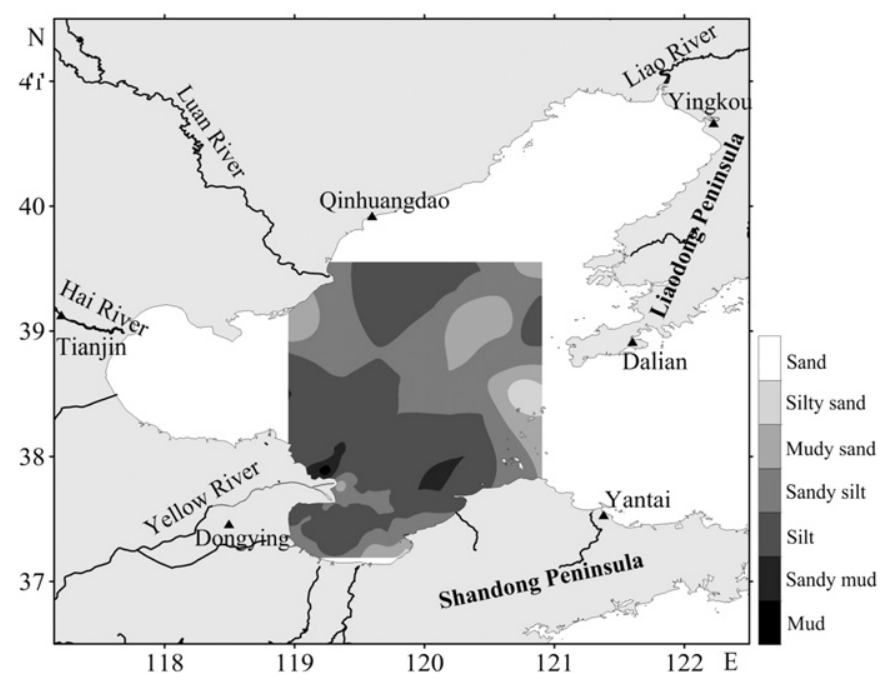

Fig. 6. The spatial distribution of sediment grain sizes in the studied area. 
Table 2

The Pearson correlations between the diatom and silicoflagellate fossils (abundance and Shannon-Weaver index) and sediment grain sizes in the studied area.

\begin{tabular}{|c|c|c|c|c|c|c|c|}
\hline \multirow[t]{2}{*}{ Items } & & \multicolumn{2}{|l|}{ Sand } & \multicolumn{2}{|l|}{ Silt } & \multicolumn{2}{|l|}{ Clay } \\
\hline & & Pearson correlation & Sig. (2-tailed) & Pearson correlation & Sig. (2-tailed) & Pearson correlation & Sig. (2-tailed) \\
\hline \multirow[t]{2}{*}{ Total sites } & $D_{\text {abs }}$ & 0.036 & 0.778 & -0.039 & 0.764 & -0.020 & 0.876 \\
\hline & $H^{\prime}$ & -0.161 & 0.207 & 0.191 & 0.133 & 0.045 & 0.728 \\
\hline \multirow[t]{2}{*}{ Group I } & $D_{\text {abs }}$ & -0.338 & 0.340 & 0.397 & 0.256 & 0.090 & 0.805 \\
\hline & $H^{\prime}$ & -0.495 & 0.146 & 0.462 & 0.179 & 0.504 & 0.137 \\
\hline \multirow[t]{2}{*}{ Group II } & $D_{\mathrm{abs}}$ & $0.483^{*}$ & $0.058^{*}$ & $-0.451^{*}$ & $0.080^{*}$ & $-0.444^{*}$ & $0.085^{*}$ \\
\hline & $H^{\prime}$ & 0.231 & 0.389 & -0.274 & 0.304 & -0.046 & 0.866 \\
\hline \multirow[t]{2}{*}{ Group III } & $D_{\text {abs }}$ & -0.044 & 0.800 & 0.055 & 0.749 & 0.009 & 0.959 \\
\hline & $H^{\prime}$ & -0.119 & 0.489 & 0.147 & 0.391 & 0.030 & 0.861 \\
\hline
\end{tabular}

Group III > Group II > Group I (Fig. 3a, b). The spatial pattern of siliceous microfossils can be related to a series of biological, chemical and physical factors. The environmental impact of sedimentation, water depth, nutrient levels, salinity and temperature are discussed below.

\subsection{The impact of environment of sedimentation}

In previous in situ surveys, high phytoplankton diversity and abundance generally occurred in surface seawater in sea areas adjacent to the Yellow River and the Laizhou Bay; this was attributed to the effect of river input, which decreases the salinity, increases nutrient levels and provides a diverse habitat for brackish and marine species (e.g., Sun et al., 2002; Sun and Liu, 2005; Sun et al., 2008). In the surface sediment, the spatial pattern of fossil diversity matched the in situ observation of surface seawaters, with higher values in the sea areas adjacent to the Yellow River and Laizhou Bay (Fig. 3b). However, the spatial pattern of fossil abundance was just the opposite, with higher values in the Central Bohai Sea and Bohai Strait (Fig. 3a). The inconsistent spatial pattern of abundance in the surface sediment and upper water column could be strongly related to the sedimentary environment in the Bohai Sea.

The deposition rates in the Bohai Sea have been demonstrated to show significant spatial variation (e.g., Ren and Shi, 1986; Zhu and Chang, 2000; Li et al., 2002). Li et al. (2002) mapped the spatial variations in the Bohai Sea deposition rates and found that very high deposition rates occurred in the mouth of the Yellow River and the Laizhou Bay, with a range of $1-9 \mathrm{~cm} / \mathrm{yr}$. The deposition rate of the Central Bohai Sea, however, only varied from 0.1 to $0.4 \mathrm{~cm} / \mathrm{yr}$, with the exception of one site that reached $1 \mathrm{~cm} / \mathrm{yr}$. Qiao et al. (2010) compared the tidal current speeds in the Baohai Strait (1.5-2.0 m/s), Central Bohai Sea $(0.5-1.0 \mathrm{~m} / \mathrm{s})$ and Laizhou Bay $(0.5 \mathrm{~m} / \mathrm{s})$; they suggested that the weak tidal current and high Yellow River input jointly contributed to the highest sediment deposition and burial rates in the mouth of the Yellow River and the Laizhou Bay. Deposition rate is an important factor that could influence the geographic distribution of fossils, and a high deposition rate can increase the burial speed and dilute the fossil abundance during the preservation process (Crosta and Koç, 2007); this can reasonably explain the low fossil abundance in the Laizhou Bay (Fig. 3a).

Sediment grain size is another important factor affecting the preservation of fossils. Generally, sandy silt and muddy sand better preserve fossils than sand (Méléder et al., 2007). In the Bohai Sea, the sediment sources are from river inputs, atmospheric deposition and the Yellow Sea intrusion; among them, river inputs reach 90\%, with the Yellow River being the major contributor (Qiao et al., 2010). Approximately $70 \%$ of sediments from the Yellow River contribute to the formation of the river delta, while the rest of the sediments diffuse and transport into coastal waters following circulation (Cheng et al., 2004). Sediment transport by the Yellow River can significantly affect the sediment grain size in the southern Central Bohai Sea and Laizhou Bay (Cheng et al., 2004; Qiao et al., 2010), which is reflected in our study (Fig. 6). The correlation between grain size and fossils was analyzed in this study (Table 2). No significant correlation was found in Groups I and III due to the lower spatial heterogeneity of grain size (Fig. 6); however, the sediment grain sizes in Group II (Central Bohai Sea) displayed higher spatial heterogeneities due to inputs from both the Yellow River and the Yellow Sea (Fig. 6). Thus, significant correlations with fossils (a positive correlation with sandy and negative correlations with silt and

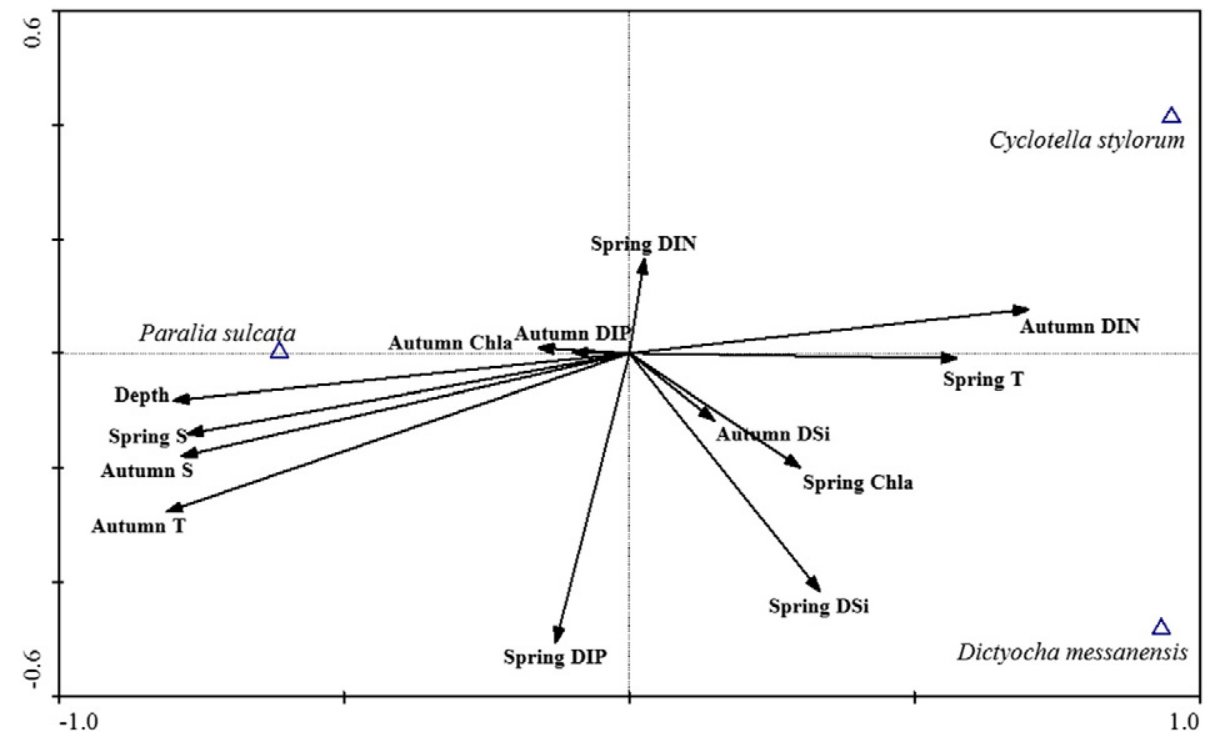

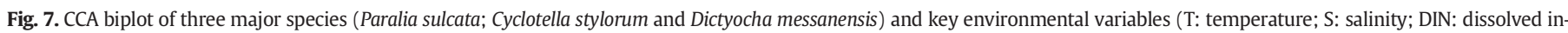
organic nitrogen; DIP: dissolved inorganic phosphate; DSi: dissolved inorganic silicate; Chl a: chlorophyll a). 
clay; Table 2) were observed for Group II, indicating that fine sediments preserve fossils better than coarse sediments.

\subsection{Siliceous microfossils as an indicator of environmental conditions}

In this study, the spatial distribution of three biofacies indicated significant environmental differences among the Laizhou Bay, Central Bohai Sea and Bohai Strait (Fig. 4b). For example, the increased proportions of brackish species in Group III clearly demonstrated the impact of river input. The most significant change is spatial shift of dominant species from the dominance of $P$. sulcata in the Central Bohai Sea and Bohai Strait to the dominance of $C$. stylorum and D. messanensis in the Laizhou Bay (Table 1 and Fig. 4). A correlation analysis between key environmental factors (water depth, sea temperature, salinity and nutrient) and three major species is shown in Fig. 7 to discern the roles of fossils as indicators of environmental conditions.

$P$. sulcata displayed a significantly positive correlation with water depth, salinity and autumn sea temperature (Fig. 7). P. sulcata has a wide salinity range (5-35) (Simonsen, 1962), but it is sensitive to temperature and is usually abundant during warmer periods, rich nutrient conditions and within a salinity range of 25-35 (Hasle et al., 1996; Zong, 1997; McQuoid and Hobson, 2001). Due to its high abundance in the surface sediment along the pathway of the YSWC, this species has been described as an indicator of the YSWC (Wang et al., 1985; Jiang, 1987; Cheng and Cao, 1991). The sea temperatures in the Bohai Strait and Central Bohai Sea are significantly influenced by the YSWC in late autumn and winter and can be $3-5{ }^{\circ} \mathrm{C}$ higher than that in coastal waters (Song et al., 2007). Corresponding to the variation of sea temperature and salinity, the abundance of $P$. sulcata in the surface sediment gradually decreased from the Bohai Strait and Central Bohai Sea to Laizhou Bay (Fig. 8a), indicating the scale of the YSWC intrusion. $P$. sulcata in the surface sediment was also positively correlated with autumn Chlorophyll a (Chl a) and dissolved inorganic phosphate (DIP) (Fig. 7), which is consistent with the in situ surveys of surface waters. P. sulcata was dominant in the Central Bohai Sea and Bohai Strait during autumn and winter; the increased phosphate brought by the YSWC can significantly enhance the growth of $P$. sulcata (e.g., Kang, 1991; Wang and Kang, 1998; Sun et al., 2002, 2008).

C. stylorum displayed a significantly negative correlation with salinity and water depth. C. stylorum is considered to favor brackishwater (e.g., McQuoid and Hobson, 2001; Mirabdullayev et al., 2004) and usually dominates in coastal waters with salinities of $\leq 31$ (Jiang, 1987). The annual average salinity in the Bohai Sea is approximately $30-31$, which is mainly controlled by the amount of river input and Yellow Sea intrusion. In summer, increased river inputs and rainfall can significantly decrease the salinity in coastal waters, when they can reach 22-24; in winter, the intrusion of high-salinity YSWC can increase the salinity to a range of 28-32 (Lin et al., 2001). In this study, the spatial distribution of $C$. stylorum abundance clearly matched the salinity gradient (Fig. 8b). C. stylorum was also positively correlated with dissolved inorganic nitrogen (DIN) (Fig. 7). Although this species is known to grow best in oligotrophic waters, a few studies have reported that it flourishes during the eutrophic process (Celik and Ongun, 2008; Liu et al., 2008; Cheng et al., 2014).

D. messanensis displayed significant positive correlations with dissolved inorganic silicate (DSi) and spring Chl a, but negative correlations with salinity and water depth (Fig. 7). This indicates that the contribution of $D$. messanensis to phytoplankton biomass is significant in spring and that this species may have a high demand on dissolved silicate. D. messanensis is a cosmopolitan species that can adapt to a wide range of temperatures (Poelchau, 1976); however, it is especially sensitive to nutrient input and occurs in high abundance in areas with river influence (Rigual-Hernández et al., 2010; Godrijan et al., 2012). In our study, the proportion of this species dominated in the Laizhou Bay and sea areas adjacent to the Yellow River, in agreement with the results of previous studies (Fig. 8c).

\section{Conclusions}

Analysis of the spatial patterns of diatom and silicoflagellate fossils in the surface sediments of the Bohai Sea, shows three biofacies representing the Laizhou Bay, Central Bohai Sea and Bohai Strait. The
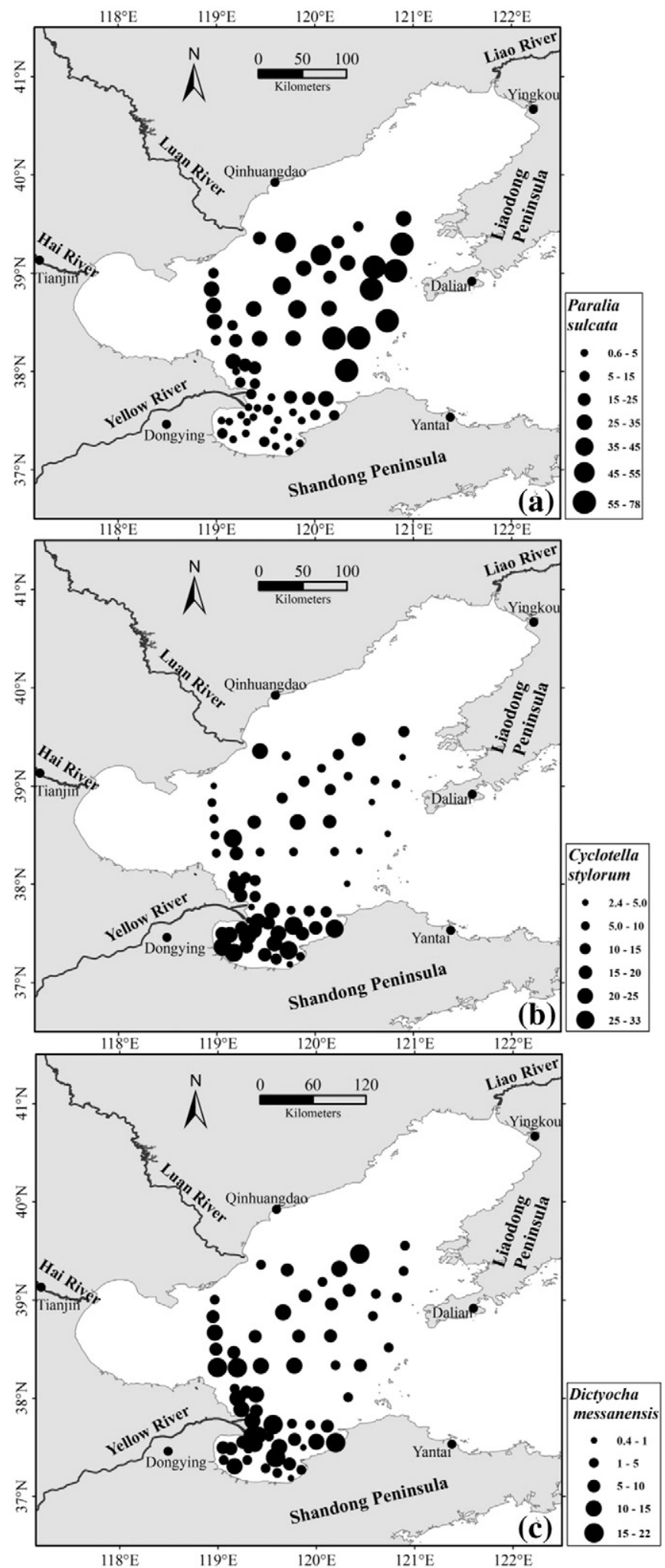

Fig. 8. The spatial variations of the proportions of three indicative species (\%) in total siliceous fossils: (a) Paralia sulcata; (b) Cyclotella stylorum; (c) Dictyocha messanensis. 
interactions between the Yellow River discharge and Yellow Sea intrusion play an important role on the three-layer spatial pattern by changing the sedimentation environment, thermohaline circulation and nutrient concentrations. Three indicative species, P. sulcata, C. stylorum and $D$. messanensis, were identified in this study. P. sulcata is a good indicator of the main region of YSWC intrusion, while C. stylorum and $D$. messanensis indicate the scale of Yellow River discharge in the Bohai Sea.

Supplementary data to this article can be found online at http://dx. doi.org/10.1016/j.marmicro.2014.11.002.

\section{Acknowledgments}

We appreciated the help of Dr. McCartney with the English language improvement and the analysis of silicoflagellate fossils in this study. This study was funded by the Natural Science Foundation of China (41376121) and the Strategic Priority Research Program of the Chinese Academy of Sciences (XDA11020405).

\section{References}

Barron, A., Burky, D., 2007. Development of the California Current during the past 12,000 yr based on diatoms and silicoflagellates. Palaeogeogr. Palaeoclimatol. Palaeoecol. 248, 313-338.

Battarbee, R.W., Jones, V.J., Flower, R.J., Cameron, N.G., Bennion, H., Carvalho, L., Stephen, J., 2001. Diatoms. In: Smol, J.P., Birks, H.J.B., Last, W.M. (Eds.), Tracking Environmental Change Using Lake Sediments. Kluwer Academic Publishers, Dordrecht, pp. 155-203.

Berglund, B.E., Sandgren, P., Barnekow, L., Hannon, G., Jiang, H., Skog, G., Yu, S.Y., 2005. Early Holocene history of the Baltic Sea, as reflected in coastal sediments in Blekinge, southeastern Sweden. Quat. Int. 130 (1), 111-139.

Buffen, A., Leventer, A., Rubin, A., Hutchins, T., 2007. Diatom assemblages in surface sediments from the northwestern Weddell Sea, Antarctic Peninsula. Mar. Micropaleontol. 62, 7-30.

Celik, K., Ongun, T., 2008. Spatial and temporal dynamics of the steady-state phytoplankton assemblages in a temperate shallow hypertrophic lake (Lake Manyas, Turkey). Limnology 9 (2), 115-123.

Cheng, G.F., Cao, Y.Q., 1991. The quantitative study of the diatoms in surface sediments of central southern part of Bohai Sea. J. Ocean Univ. Qingdao 21 (4), 56-74.

Cheng, Z.D., Gao, Y.H., Dickman, M., 1996. Colour Plates of the Diatoms. China Ocean Press, Beijing, China (in Chinese)

Cheng, P., Gao, S., Bokuniewicz, H., 2004. Net sediment transport patterns over the Bohai Strait based on grain size trend analysis. Estuar. Coast. Shelf Sci. 60 (2), 203-212.

Cheng, F., Yu, Z., Song, X., 2014. Long-term changes in sedimentary diatom assemblages and their environmental implications in the Changjiang (Yangtze) River estuary, China. Chin. J. Oceanol. Limnol. 329 (1), 155-161.

Chin, T.G., Cheng, Z.D., Liu, S.C., M, J.T., 1992. Marine Benthic Diatoms from China II. Beijing, China, China Ocean Press (in Chinese).

Crosta, X., Koç, N., 2007. Diatoms: from micropaleontology to isotope geochemistry. In: Hilaire-Marcel, C., De Vernal, A. (Eds.), Proxies in Late Cenozoic Paleoceanography, Developments in Marine Geology Series vol.1. Elsevier, Amsterdam, The Netherlands, pp. 327-369.

Dawes, C.J., 1998. Marine Botany. 2nd ed. John Wiley and Sons, Inc., New York, p. 484.

Folk, R.L., Andrews, P.B., Lewis, D.W., 1970. Detrital sedimentary rock classification and nomenclature for use in New Zealand. N. Z. J. Geol. Geophys. 13 (4), 937-968.

Godrijan, J., Marić, D., Tomažić, I., Precali, R., Pfannkuchen, M., 2012. Seasonal phytoplankton dynamics in the coastal waters of the north-eastern Adriatic Sea. J. Sea Res. 77, 32-44.

Guan, B.X., 1994. Patterns and structures of the currents in Bohai, Huanghai and East China Sea. In: Zhou, D., Liang, Y.B., Tseng, C.K. (Eds.), Oceanology of China Sea. Kluwer Academic Publishers, The Netherlands, pp. 17-26.

Guo, Y.J., Qian, S.B., 2003. Marine Bacillariophyta Centricae Flora China Sea. Science Press, Beijing (in Chinese).

Hainbucher, D., Wei, H., Pohlmann, T., Sündermann, J., Feng, S., 2004. Variability of the Bohai Sea circulation based on model calculations. J. Mar. Syst. 44 (3-4), 153-174.

Hasle, G.R., Syvertsen, E.E., Steidinger, K.A., Tangen, K., Tomas, C.R., 1996. Marine diatoms. In: Tomas, C.R. (Ed.), Identifying Marine Diatoms and Dinoflagellates. Academic Press, San Diego, pp. 5-386.

Hickox, R., Belkin, I., Cornillon, P., Shan, Z.Q., 2000. Climatology and seasonal variability of ocean fronts in the East China, Yellow and Bohai Seas from satellite SST data. Geophys. Res. Lett. 27 (18), 2945-2948.

Jiang, H., 1987. Diatoms in surface sediments in coastal China seas. Acta Oceanol. Sin. 9 (6), 735-743 (in Chinese, with English abstract).

Jiang, H., Zheng, Y.L., Ran, L.H., Seidenkrantz, M.S., 2004. Diatoms from the surface sediments of the South China Sea and their relationships to modern hydrography. Mar. Micropaleontol. 53 (3), 279-292.
Kang, Y.D., 1991. Distribution and seasonal variation of phytoplankton in the Bohai Sea Mar. Fish. Res. 12, 31-44 (in Chinese, with English abstract).

Li, F.Y., Gao, S., Jia, J.J., Zhao, Y.Y., 2002. Contemporary deposition rates of fine grained sediment in the Bohai and Yellow Seas. Oceanol. Limnol. Sin. 33 (4), 364-369 (in Chinese, with English abstract).

Lin, C.L., Su, J.L., Xu, B.R., Tang, Q.S., 2001. Long-term variations of temperature and salinity of the Bohai Sea and their influence on its ecosystem. Prog. Oceanogr. 49, 7-19.

Liu, D.Y., Wang, Y.Q., 2013. Trends of satellite derived chlorophyll-a (1997-2011) in the Bohai and Yellow Seas, China: effects of bathymetry on seasonal and inter-annual patterns. Prog. Oceanogr. 116, 154-166.

Liu, D.Y., Sun, J., Zhang, J., Liu, G.S., 2008. Response of the diatom flora in Jiaozhou Bay, China to environmental changes during the last century. Mar. Micropaleontol. 66, 279-290.

Liu, S.M., Li, L.W., Zhang, Z., 2011. Inventory of nutrients in the Bohai. Cont. Shelf Res. 31, $1790-1797$.

Mao, X., Jiang, W., Zhao, P., Gao, H., 2008. A 3-D numerical study of salinity variations in the Bohai Sea during the recent years. Cont. Shelf Res. 28 (19), 2689-2699.

McQuoid, M.R., Hobson, L.A., 2001. A Holocene record of diatom and silicoflagellate microfossils in sediments of Saanich Inlet, ODP Leg 169S. Mar. Geol. 174 (1-4), 111-123.

Méléder, V., Rincé, Y., Barillé, L., Gaudin, P., Rosa, P., 2007. Spatiotemporal changes in microphytobenthos assemblages in a macrotidal flat (Bourgneuf Bay, France). J. Phycol. 43 (6), 1177-1190.

Mirabdullayev, I.M., Joldasova, I.M., Mustafaeva, Z.A., Kazakhbaev, S., Lyubimova, S.A., Tashmukhamedov, B.A., 2004. Succession of the ecosystems of the Aral Sea during its transition from oligohaline to polyhaline water body. J. Mar. Syst. 47 (1), 101-107.

Poelchau, H.S., 1976. Distribution of Holocene silicoflagellates in North Pacific sediments. Micropaleontology 22 (2), 164-193.

Qiao, S.Q., Shi, X.F., Wang, G.Q., Yang, G., Hu, N.J., Liu, S.F., Liu, Y.G., Zhu, A.M., Li, C.X., 2010. Discussion on grain-size characteristics of seafloor sediment and transport pattern in the Bohai Sea. Acta Oceanol. Sin. 32 (4), 139-147 (in Chinese, with English abstract).

Ren, M.E., Shi, Y.L., 1986. Sediment discharge of the Yellow River (China) and its effect on the sedimentation of the Bohai and the Yellow Sea. Cont. Shelf Res. 6 (6), 785-810.

Renberg, I., 1990. A procedure for preparing large sets of diatom slides from sediment cores. J. Paleolimnol. 4 (1), 87-90.

Rigual-Hernández, A.S., Bárcena, M.A., Sierro, F.J., Flores, J.A., Hernández-Almeida, I., Sanchez-Vidal, A., Palanques, A., Heussner, S., 2010. Seasonal to interannual variability and geographic distribution of the silicoflagellate fluxes in the Western Mediterranean. Mar. Micropaleontol. 77, 46-57.

Sancetta, C., 1990. Seasonal occurrence of silicoflagellate morphologies in different environments of the eastern Pacific Ocean. Mar. Micropaleontol. 16 (3), 285-291.

Shannon, C., Weaver, W., 1949. The Mathematical Theory of Communication. University of Illinois Press, Urbana.

Simonsen, R., 1962. Untersuchungen zur Systematik und Ökologie der Bodendiatomeen der westlichen Ostsee. Int. Rev. Gesamten Hydrobiol. Syst. Beih. 1, 1-144.

Smol, J.P., Stoermer, E.F., 2010. Applications and uses of diatoms: prologue. In: Smol, J.P., Stoermer, E.F. (Eds.), The Diatoms: Applications for the Environmental and Earth Sciences, 2nd ed. Cambridge University Press, New York, pp. 3-7.

Song, D.H., Yu, H.M., Bao, X.W., 2007. Analysis of the interannual variability of the eastern China seas and its adjacent seas surface temperature. Period. Ocean Univ. China 37 21-28 (Sup., in Chinese)

$\mathrm{Su}$, J.L., 1998. Circulation dynamics of the China Seas north of $180^{\circ} \mathrm{N}$. In: Robinson, A.R. Brink, K.H. (Eds.), The Sea vol. 11. John Wiley \& Sons Inc., New York, pp. 483-505.

Sun, J., Liu, D.Y., 2005. Net-phytoplankton community of the Bohai Sea in the autumn of 2000. Acta Oceanol. Sin. 27 (3), 124-132 (in Chinese, with English abstract).

Sun, J., Liu, D.Y., Yang, S.M., Guo, J., Qian, S.B., 2002. The preliminary study on phytoplankton community structure in the central Bohai Sea and the Bohai Strait and its adjacent area. Oceanol. Limnol. Sin. 33 (5), 461-471 (in Chinese, with English abstract).

Sun, P., Li, R.X., Li, Y., Zhu, M.Y., Xu, Z.J., 2008. The net-phytoplankton community structure of the Bohai Sea in late summer, 2005. Adv. Mar. Sci. 26 (3), 354-363 (in Chinese, with English abstract).

Ter Braak, C.J.F., Smilauer, P., 2002. Canoco for Windows version 4.5. Biometris-Plant Research International, Wageningen.

Wang, J., Kang, Y.D., 1998. Study on population dynamics of phytoplankton in the Boha Sea. Mar. Fish. Res. 19 (1), 43-52 (in Chinese, with English abstract).

Wang, K.F., Jiang, H., Zhang, Y.L., Wang, Y.J., Xu, J.S., 1985. Environmental discussion on distribution of the diatom in the surface sediments of the Huanghai Sea. Oceanol. Limnol. Sin. 16 (5), 400-409 (in Chinese, with English abstract).

Wang, H., Yang, Z.S., Saito, Y., Liu, J.P., Sun, X.X., 2006. Interannual and seasonal variation of the Huanghe (Yellow River) water discharge over the past 50 years: connections to impacts from ENSO events and dams. Glob. Planet. Chang. 50, 212-225.

Whitehead, J.M., Bohaty, S.M., 2003. Pliocene summer sea surface temperatures reconstruction using silicoflagellates from South Ocean ODP Site 1165. Paleoceanography 18 (3), 1075.

Zhu, Y., Chang, R., 2000. Preliminary study of the dynamic origin of the distribution pattern of bottom sediments on the continental shelves of the Bohai Sea, Yellow Sea and East China Sea. Estuar. Coast. Shelf Sci. 51 (5), 663-680.

Zong, Y., 1997. Implications of Paralia sulcata abundance in Scottish isolation basins. Diatom Res. 12 (1), 125-150. 